九州大学学術情報リポジトリ

Kyushu University Institutional Repository

\title{
A Study on Interpersonal Relationships, Market Orientation and Performance of Chinese Garlic
} Farmers

Geng, Xianhui

College of Economics and Management, Nanjing Agricultural University

Fukuda, Susumu

Laboratory of Food Marketing and Distribution, Division of Agricultural and Resource

Economics, Department of Agricultural and Resource Economics, Faculty of Agriculture, Kyushu University

Moritaka, Masahiro

Laboratory of Food Marketing and Distribution, Division of Agricultural and Resource

Economics, Department of Agricultural and Resource Economics, Faculty of Agriculture, Kyushu University

Zhou

College of Economics and Management, Nanjing Agricultural University

他

https://doi.org/10.5109/27377

出版情報: 九州大学大学院農学研究院紀要. 58 (2)，pp.439-447，2013-09. Faculty of Agriculture， Kyushu University

バージョン：

権利関係 : 


\title{
A Study on Interpersonal Relationships, Market Orientation and Performance of Chinese Garlic Farmers
}

\author{
Xianhui GENG ${ }^{1}$, Susumu FUKUDA ${ }^{2 *}$, Masahiro MORITAKA ${ }^{2}$, \\ Yingheng $\mathrm{ZHOU}^{1}$ and Qiang $\mathrm{LI}^{2}$
}

\author{
Laboratory of Food Marketing and Distribution, Division of Agricultural and Resource Economics, \\ Department of Agricultural and Resource Economics, Faculty of Agriculture, \\ Kyushu University, Fukuoka 812-8581, Japan \\ (Received April 26, 2013 and accepted May 9, 2013)
}

\begin{abstract}
The study uses survey data gathered in August 2012 from the primary garlic-producing area of China, which is located in Jinxiang County in Shandong Province, to create a structural equation model that permits the analysis of the causal relationships among garlic farmers' interpersonal relationships, market orientations, innovation and performance. The study results reveal that Chinese garlic farmers' market orientations can exert positive impacts on their performance; these influences occur indirectly through the mediators of innovation. Chinese farmers' strength of interpersonal relationships can significantly enhance their market orientation levels and indirectly promote improved performance. The policy implication of these findings is that the Chinese government should acknowledge the important role of interpersonal relationships and provide farmers with more information about consumer needs and new cultivation techniques; this information could help farmers evaluate their situations and make sound decisions that enhance both their market orientation levels and their performances.
\end{abstract}

Key words: market orientation, performance, personal relationship, structural equation model

\section{INTRODUCTION}

The objective of improving farmer incomes is both the first and last goal of agricultural policy. Particularly in developing countries, more attention should be devoted to farmer performance and the examination of considerations that affect poor farmers' final income levels and well-being. What factors affect farmer performance? Many researchers have conducted extensive studies and discussions that address two different perspectives with respect to this problem. One perspective involves analyzing the objective factors that can affect farmer performance. These objective factors include the adoption of new varieties, non-farm employment, demographic characteristics, farm characteristics, management strategies, marketing channel selection and technical training, among other considerations. The other perspective involves focusing on subjective factors for farmers, such as their motivation, partner trust, innovation and psychological elements, and exploring how these factors can affect farmer performance.

First, the objective factors that affect farmers' performance are discussed. (1) Agricultural technology, particularly the adoption of new varieties, can improve farmer performance. Lawal et al. (2004) found that the use of new and improved maize varieties in southern Nigeria not only improved corn production but also increased farmers' income by 53.1\%. Similarly, Brocke et

${ }^{1}$ College of Economics and Management, Nanjing Agricultural University, Nanjing 210095, China

${ }^{2}$ Laboratory of Food Marketing and Distribution, Division of Agricultural and Resource Economics, Department of Agricultural and Resource Economics, Faculty of Agriculture, Kyushu University, Fukuoka 812-8581, Japan

* Corresponding author(E-mail: sufukuda@agr.kyushu-u.ac.jp) al. (2003) determined that farmers in the northwest of India could increase their yield of pearl millet (one of the major local agricultural products) through improvements in seed technology. Chitere et al. (1985) verified the positive causal relationship between agricultural technology promotion projects and farmer performance in a Kenyan context. (2) Farmers' demographic characteristics and their farms' physical characteristics can also affect their performance. Ashok et al. (2009) proposed that those factors affecting farmers' performance can be classified into three categories: farmers' demographic characteristics, farm characteristics (including production and marketing efficiency) and management strategies. These researchers' results revealed that an inverted U-shaped relationship existed between the age and performance of farmers. Furthermore, correct management strategies led to improvements in farmer performance. Amos (2007) used the stochastic frontier production function to examine cocoa production in Nigeria and found that the age, education level and family size of farmers had significant impacts on the productivity of these farmers. Based on survey data from Norwegian grain farms, Gudbrand et al. (2010) determined that non-farm employment produced a significant and positive effect on grain production. However, this effect was characterized by an inverted U-shape; over the course of time, the observed output initially increased but subsequently decreased. Ishag et $a l$. (1991) found that different geographical sites for cotton and wheat farms in Sudan generated different production and income levels. In middling and poor locations for these farms, groundnut cultivation yielded a substantially higher net return per hectare than cotton or wheat farming. (3) Sales channels and information training can also improve farmer performance. Meike et al. (2007) employed a two-stage least squares method to analyze 
coffee grower performance and determined that growers who participated in contract farming enjoyed significantly increased selling prices for their goods compared with growers who sold their products through traditional channels. Haefele (2002) concluded that if farmers were given better access to information, improved rice technologies and inputs, rice production on irrigated land in West Africa might exhibit rapid advances. Dhaka et al. (2009) examined garlic growers in particular and determined that technical training would significantly increase the productivity and net incomes of these farmers.

Although farmer performance has traditionally been assessed through analyses of the aforementioned objective factors, such as demographic characteristics, farm characteristics, inputs and technologies, the development of behavioral economics has prompted several recent studies to devote attention to farmers' psychological characteristics and examine the causal relationship between the mental activities and the performances of farmers. Joyce (1999) described the domains of farmers' attitudes, goals and behaviors. This study provided scales for the measurement of subjective variables and examined the correlations among farmers' attitudes, goals and behaviors. Masuku (2004) investigated the role of trust in the performances of aspects of the sugar industry supply chain in Swaziland. This study assessed the perceptions of 124 smallholder sugarcane growers; in particular, items presented with Likert-type scales were used to measure the sampled cane growers' trust in their millers. The study results indicated that farmers who had trust in their millers performed better than farmers without this trust; thus, this trust contributed to the performance of the entire supply chain. Kabiri et al. (2012) investigated the entrepreneurial orientations of Iranian farmers and the impact of this orientation on farmers' performances. These researchers' results revealed that farmers who displayed high levels of entrepreneurship orientation typically evinced higher levels of performance. A Spearman rank correlation test was utilized by Guntoro (2007) to examine Indonesian beef farmers' motives and the impacts of these motives on performance (as measured by the farmers' levels of technology adoption and net income). The results of this study revealed that economic needs, food safety needs, care needs, self-esteem needs and self-actualization needs were the major motivations of the examined farmers. Farmers who possessed stronger motivations reached a higher level of performance with respect to both net income and the adoption of technology. Tarabla et al. (1990) utilized survey data and multivariable methods to evaluate how the personal characteristics and management policies of farmers in eastern Ireland affected the quality and quantity of their farms' milk production. The results of this investigation revealed that farmers' attitudes and values exerted positive and significant effects on their performances.

The objective factors affecting farmers' performances that are discussed above, such as demographic characteristics, land characteristics, capital investment characteristics and the adoption of technology, are the primary factors that are referenced in agricultural production functions. The subjective factors that affect farmer performance are psychological and include attitude, motivation, trust and innovation. From recent trends in research addressing farmer performance, we can observe that several studies have begun to focus on the relationship between farmers' market orientations and their performances. However, there remain few studies in the field of agriculture that address market orientation; in fact, several recent investigations in agriculture have derived their ideas and methodologies from market orientation studies in the field of industrial enterprise. Micheels et al. (2008), Johnson et al. (2009) and Verhees et al. (2011) were the first researchers to introduce the concept of the market orientation of industrial enterprise to the field of agriculture. Johnson et al. examined the market orientations of American food enterprises and the impact of these orientations on performance. Micheels et al. validated the causal relationship between the market orientations and performances of American beef suppliers. Verhees et al. studied the market orientations of Dutch horticultural producers and the causal relationship between these market orientations and performance levels.

The contribution of Chinese farmers to worldwide agricultural production is very small, and the degree of organization among these farmers is very low; in these respects, small-scale Chinese farmers differ greatly from the large farmers and food processing companies in Europe and the United States. What factors affect the performances of these Chinese farmers? Would market orientation impact the performances of these farmers, and what functional mechanisms would produce this effect? To date, no studies have focused on this topic. The most important consideration with respect to this topic is that farmers' market orientations should be based on the precondition that they receive comprehensive information about the desires of consumers and the needs of channel partners. In Europe and the United States, this information is provided for the public good by various associations or governmental bodies. However, in China, the government's concern for the public good is inadequate, and small-scale Chinese farmers primarily depend on their strength of interpersonal relationships to receive market information. Thus, will the market orientation of Chinese farmers be affected by their strength of interpersonal relationships? This issue is very important for small-scale Chinese farmers. We incorporate this consideration into our research and examine the causal links among Chinese farmers' interpersonal relationships, market orientations, innovation and performance. This study seeks to fill the research gap in the extant literature by contributing information regarding Chinese farmers' market orientations and the impact of these orientations on performance. The investigation of the relevance of Chinese farmers' interpersonal relationships and market orientations to farmer performance constitutes the innovation of this study. The other portions of this article are organized as follows: the second section of the paper explains the model building and the data resources of this study; the third section of this article discusses the model's goodness of fit and estimates its parameters; 
and the final section of the manuscript presents conclusions and provides certain implications from the results of the investigation.

\section{MODEL BUILDING AND DATA RESOURCES}

The data that are used in this study are obtained from an August 2012 survey that was conducted in Jinxiang County, which is located in the Shandong Province of China, by the "Chinese farmers' market orientation and performance" research group. Jinxiang County is one of the primary garlic-producing areas in China, and China is the largest producer of garlic in the world. In 2010, the garlic yield of China was 18,558,700 tons, whereas the total world garlic yield was $22,561,300$ tons. Thus, China accounted for $82.26 \%$ of the world production of garlic. Garlic farmers in the main garlic-producing areas of China have high commercialization levels. In these regions, garlic is primarily produced to be sold in the marketplace rather than for subsistence purposes. As mentioned above, Jinxiang County of Shandong Province is one of the primary areas of garlic production in China. Approximately 60 million acres of this county are used to produce garlic each year, and the county generates an average annual garlic production of more than 500,000 tons.

For these reasons, Jinxiang County of Shandong Province was chosen as the target area in which we conducted our survey. We adopted a random sampling approach for this survey to obtain detailed micro-level data and information. To ensure the quality of the sample, a structured questionnaire was used in the survey. The investigators conducted face-to-face interviews with the farmers. A total of 272 farmers completed the survey, and all of the sample data were considered to be appropriate for inclusion in the analyses of this study. A structural equation model is created based on the theoretical framework and literature review of this study, and our four hypotheses are constructed in accordance with the principles derived from this literature review.

The literature on the relationship between market orientation and performance first arose in the 1990s. Kohli and Jaworski $(1990,1993)$ and Narver and Slater (1990, 1993, 1995, 1998, and 1999) were the early pioneers and founders of this field of study. The concept of market orientation mainly refers to creating values for customers by meeting consumer demands, paying attention to competitors and conducting internal coordination. To create maximal value for purchasers, enterprises adopt innovative actions and allocate resources appropriately within their organizations. Based on empirical analyses, the early researchers in this field reached the conclusion that market orientation would significantly impact performance and that there was a linear relationship between market orientation and performance level. Slater and Narver (1994) observed that in any business environment, enterprises with high levels of market orientation demonstrated better performance than other firms. Recently, Micheels and Gow (2008), Johnson et al. (2009) and Verhees et al. (2011) have introduced the early results of market orientation analysis to the fields of agriculture and food production. None of this work has contradicted the aforementioned causal relationship between market orientation and performance that was identified by earlier studies. Therefore, the first hypothesis of this study may be expressed as follows:

Hypothesis 1 Farmers with higher degrees of market orientation will demonstrate better performance.

Several recent studies have addressed the relationships among innovation, market orientation and performance. Hansen et al. (2006) defined innovation as the process of creating or adopting new ideas, new production processes, new products and new services to add value for consumers and increase the performance and efficiency of an enterprise. Thus, innovation refers to the attempts of an organization or enterprise to devise or adopt a new method to improve performance (Micheels and Gow, 2008). It is possible to improve production efficiency by adopting technological innovation and improving product quality. Hurley and Hult (1998) found that innovation was an important driving force for improving performance. Michaels and Gow (2008) determined that innovation by American beef farmers could significantly improve the performances of these farmers. Innovation can not only impact performance but also serve as a mediator that links market orientation and performance. Enterprises with high levels of market orientation typically collect information about consumers' current or future needs; if these enterprises possess innovative abilities, then they convert this market information into actions that meet the observed consumer needs. Narver and Slater (1990) conjectured that market-oriented enterprises typically evinced high levels of innovation and that this innovation would generate improved performance. Han et al. (1998) first verified that market orientation could positively affect performance through the mediator of innovation. Mavondo et al. (2003) verified that market-oriented food enterprises could significantly improve their product innovation levels and that product innovation significantly affected the performances of these firms. It is clear that innovation can function as a mediator between market orientation and performance. Thus, we propose the second and the third hypotheses of this study:

Hypothesis 2 Innovation, which can include the adoption of new varieties and new technologies, can improve the performances of farmers.

Hypothesis 3 Farmers with higher levels of market orientation will display stronger levels of innovation.

Market information about the needs of consumers and the demands of channel partners is very important for determining farmers' market orientation levels. However, in China, it is difficult for dispersed small-scale farmers, who constitute the main body of agricultural producers, to receive information from the government. Because public sources of information may be inadequate, how can small-scale Chinese farmers access effective market information to implement an appropriate market orientation? Interpersonal relationships play an important role in the agricultural production and mar- 
keting efforts of small-scale Chinese farmers. Based on Fan (2002), we define interpersonal relationships as the strength of a maintained relationship obtained through birth, by nature, or else acquired. Thus, a strong interpersonal relationships as an asset or a form of capital belonging to a person means that he or she can benefit much from the strongly maintained ties with family, teachers, classmates, neighbors, friends, business partners, and so on, some of whom are in a position to supply private and informal information related to market demand or consumer needs.

With the support of interpersonal relationships, farmers can identify new channel partners, access new markets and gather relevant market information (Standifird et $a l ., 2000)$. Increases in the strength of interpersonal relationships are conducive to information communication and coordination (Larson, 1991). In particular, smallscale Chinese farmers obtain a great deal of information about agricultural prices, consumer and channel needs, buyer preferences and other market parameters through interpersonal relationships; thus, this source of information certainly improves these farmers' abilities to implement appropriate market orientations. Thus, we propose the last hypothesis of this study:

Hypothesis 4 Farmers' strength of interpersonal relationships can effectively improve their levels of market orientation.

The aforementioned four hypotheses are derived from distilling the extant research into conjectured relationships between market orientation and performance, with a particular focus on market orientation in the field of agriculture. In our assessments, we must also consider the condition of China's agricultural production. The next step in this study will address and test these hypotheses.

Because many latent variables, such as guanxi, market orientation, innovation and performance, must be measured in this investigation, traditional regression methods cannot be directly utilized for the analyses in this study. One popular analytical approach uses a structural equation model (SEM) to assess the causal relationships among latent variables. To test the four hypotheses of this investigation, a SEM is used in this study to describe the relationships between the exogenous latent variables and the endogenous latent variables; the relationships among these variables may be modeled as follows:

$$
\begin{aligned}
& \eta=B \eta+\Gamma \xi+\zeta \\
& y=\Lambda y \eta+\varepsilon \\
& x=\Lambda x \xi+\delta
\end{aligned}
$$

Where variable $\xi$ is an exogenous latent variable that is not influenced by any other variable in the model. Typically, an exogenous latent variable affects one or more of the other variables in the model. By contrast, $\eta$ is an endogenous latent variable and is therefore affected by one or more of the other variables in the model; an endogenous latent variable may also influence another endogenous latent variable in the model. In the above equations, $\Lambda x$ and $\Lambda y$ are the coefficients of the factor loadings; B and $\Gamma$ are path coefficients; $\delta$ and $\varepsilon$ are the measurement errors of the observed variables $x$ and $y$, respectively; and $\zeta$ is the measurement error of the latent variables. Figure 1 presents the path analysis diagram that is used by the proposed structural equation model; the path parameters will be estimated from this model.

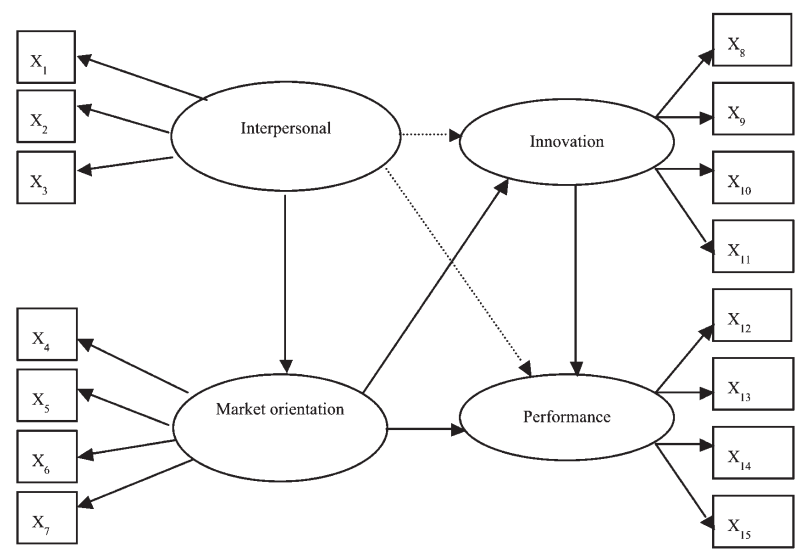

Fig. 1. Paths of the Structural Equation Model.

In order to explore other correlation ships among the latent variables, we would assume that interpersonal relationships can impact innovation and performance positively. Because these two hypotheses have no ground supports in theories and literatures, we use dotted arrow line to describe the paths.

We adopted a five-point Likert scale to measure the latent variables of interpersonal relationships, market orientation, innovation and performance. The measurement of interpersonal relationships was based on the metrics that were employed by Lu et al. (2001). The measurements of market orientation, innovation and performance were based on the metrics that were used by Micheels and Gow (2008). Given that small-scale Chinese farmers are very different from American beef farmers, we modified the scale that was used by Micheels and Gow (2008); notably, the most significant modifications were implemented for the measurements of market orientation. In the study of Micheels and Gow (2008), three aspects of market orientation were utilized: consumer concerns, competitor concerns and internal coordination. These aspects are not applicable to dispersed small-scale Chinese farmers because the large number of scattered small-scale farmers in China would not regard other Chinese farmers as competitors and because no internal coordination would be required for each individual farmers' enterprise. Thus, to measure Chinese farmers' market orientation, we primarily focused on whether Chinese farmers were motivated to satisfy the demands of consumers and channel partners.

The following three points were used to measure interpersonal relationships: whether interpersonal relationships can help a farmer find new buyers $\left(\mathrm{X}_{1}\right)$; whether interpersonal relationships can help farmers establish trust between themselves and their buyers $\left(\mathrm{X}_{2}\right)$; and 
whether interpersonal relationships can encourage farmers to access to the market $\left(\mathrm{X}_{3}\right)$. The following four points were used to measure market orientation: whether farmers are attempting to discover extra demand that consumers have not realized $\left(\mathrm{X}_{4}\right)$; whether farmers are adopting new varieties of garlic to meet customers' potential demands $\left(\mathrm{X}_{5}\right)$; whether farmers frequently visit their current or future customers $\left(\mathrm{X}_{6}\right)$; and whether farmers target their production activities to meet the needs of the market $\left(\mathrm{X}_{7}\right)$. The following four points were used to measure innovation: whether farmers regard creativity as superior to general wisdom for the purpose of solving problems $\left(\mathrm{X}_{8}\right)$; whether farmers firmly believe that changes in the market may present new business opportunities $\left(\mathrm{X}_{9}\right)$; whether farmers perceive opportunities rather than problems $\left(\mathrm{X}_{10}\right)$; and whether farmers attempt new techniques and methods for planting their crops $\left(\mathrm{X}_{11}\right)$. The following four points were used to measure performance: whether farmers were very satisfied with their agricultural performance in the previous year $\left(\mathrm{X}_{12}\right)$; whether farmers demonstrated an agricultural performance in the previous year that surpassed the average performance level in their village $\left(\mathrm{X}_{13}\right)$; whether farmers obtained high returns on their market investments $\left(\mathrm{X}_{14}\right)$; and whether farmers enjoyed agricultural product prices in the previous year that were higher than the average price levels of their village $\left(X_{15}\right)$.

In this study, we used the SPSS.20 software program to perform confirmatory factor analyses and the AMOS.20 software program to perform structural equation analyses.

\section{GOODNESS-OF-FIT TEST AND PARAMETERS ESTIMATION}

The $\mathrm{t}$ parameter is commonly used to determine whether a model is identifiable. In total, there are $(m+n)$ observable variables in the structural equation model, where $m$ is the number of exogenous measured variables and $n$ is the number of endogenous measured variables. The parameter $t$ represents the number of free parameters that need to be estimated in the model. Therefore, the necessary condition for the model to be identifiable may be expressed as $\mathrm{t} \leq(\mathrm{m}+\mathrm{n}) *(\mathrm{~m}+\mathrm{n}+1) / 2$.

Our structural equation model contains 47 free parameters and 15 observed variables. Because $47 \leq$ $(11+4) *(11+4+1) / 2=120$, the structural equation model is identifiable. We used 272 samples to perform the structural equation model analyses. Bentler and Chou (1987) provided the rule of thumb that under normal distribution theory, the ratio of sample size to the number of free parameters should be at least 5:1 to obtain reliable parameter estimates. Because the number of free parameters in our model is 47 , the minimum sample size should therefore be greater than 235. Thus, according to the 5:1 rule, our sample size is sufficient to permit reliable analysis. After ensuring that the sample size is sufficiently large and that the structural equation is identifiable, the next step in the analysis involves testing the reliability and validity of the measured variables. Reliability refers to the credibility of a measurement, which is evaluated based on whether the indicated items can consistently reflect the latent variable in the model. Cronbach (1951) proposed that the coefficient $\alpha$ can be used to measure the reliability of a Likert scale. Values of $\alpha$ that are closer to 1 indicate higher reliability. In general, if $\alpha$ is greater than or equal to 0.7 , the internal consistency of a measurement is high (Kim, 1978); if $\alpha$ is between 0.35 and 0.7 , the internal consistency of a measurement is moderate; and if $\alpha$ is less than 0.35 , the internal consistency of a measurement is low. In a confirmatory factor analysis, a single factor loading that is greater than 0.6 can illustrate that a model has good reliability and validity (Nunnally, 1994). The following table 1 and table 2 present the descriptive statistics, reliability and validity of the measured variables.

Table 1. Descriptive Statistics

\begin{tabular}{cccc}
\hline $\begin{array}{c}\text { Observed } \\
\text { variables }\end{array}$ & Mean & Std. Deviation & Variance \\
\hline $\mathrm{X}_{1}$ & 3.23 & .798 & .636 \\
$\mathrm{X}_{2}$ & 3.11 & .865 & .748 \\
$\mathrm{X}_{3}$ & 3.02 & .846 & .715 \\
$\mathrm{X}_{4}$ & 2.81 & .805 & .647 \\
$\mathrm{X}_{5}$ & 2.69 & .709 & .502 \\
$\mathrm{X}_{6}$ & 2.53 & .773 & .597 \\
$\mathrm{X}_{7}$ & 2.70 & .818 & .669 \\
$\mathrm{X}_{8}$ & 3.43 & .639 & .409 \\
$\mathrm{X}_{9}$ & 3.46 & .675 & .456 \\
$\mathrm{X}_{10}$ & 3.29 & .643 & .413 \\
$\mathrm{X}_{11}$ & 3.19 & .746 & .556 \\
$\mathrm{X}_{12}$ & 2.69 & .740 & .548 \\
$\mathrm{X}_{13}$ & 2.74 & .674 & .454 \\
$\mathrm{X}_{14}$ & 2.59 & .768 & .589 \\
$\mathrm{X}_{15}$ & 2.70 & .741 & .549 \\
\hline
\end{tabular}

From table 1 we can see that all the values of items' standard deviations are below 0.85 , which means that the sample item values are grouped closely together. Another way of saying it is that the range of item values is small. To this extent, our survey data quality is satisfying. Furthermore, the value of strength of interpersonal relationships is relatively high, showing that interpersonal relationships should play an important role in Chinese farmers' agricultural marketing. The value of innovation is relatively high too, which means that the innovation of Chinese garlic farmers might be important to their performance.

We can see from the table 2 that all of the alpha coefficients are greater than 0.75 , indicating a high level of reliability. Furthermore, as indicated in Table 1, the results of the confirmatory factor analysis reveal that the factor loadings of the measured variables that are selected by the model are all greater than $75 \%$. Thus, our data and model display high levels of reliability and validity and 
Table 2. The Reliability and Validity of the Measured Variables

\begin{tabular}{|c|c|c|c|c|}
\hline $\begin{array}{c}\text { Latent } \\
\text { variables }\end{array}$ & $\begin{array}{c}\text { Measurable } \\
\text { variable }\end{array}$ & $\begin{array}{l}\text { Correlation } \\
\text { coefficient }\end{array}$ & $\begin{array}{c}\text { Factor } \\
\text { loadings }\end{array}$ & $\alpha$ coefficient \\
\hline Interpersonal & $\mathrm{X}_{1}$ & 0.620 & 0.835 & \\
\hline \multirow[t]{3}{*}{ relationships } & $\mathrm{X}_{2}$ & 0.746 & 0.861 & 0.820 \\
\hline & $\mathrm{X}_{3}$ & 0.670 & 0.805 & \\
\hline & $\mathrm{X}_{4}$ & 0.658 & 0.816 & \\
\hline Market & $X_{5}$ & 0.683 & 0.827 & 0.842 \\
\hline \multirow[t]{3}{*}{ orientation } & $\mathrm{X}_{6}$ & 0.681 & 0.823 & \\
\hline & $\mathrm{X}_{7}$ & 0.688 & 0.832 & \\
\hline & $\mathrm{X}_{8}$ & 0.590 & 0.787 & \\
\hline \multirow[t]{4}{*}{ Innovation } & $\mathrm{X}_{9}$ & 0.601 & 0.798 & 0.772 \\
\hline & $\mathrm{X}_{10}$ & 0.590 & 0.779 & \\
\hline & $X_{11}$ & 0.524 & 0.727 & \\
\hline & $\mathrm{X}_{12}$ & 0.613 & 0.777 & \\
\hline \multirow[t]{3}{*}{ Performance } & $X_{13}$ & 0.676 & 0.827 & 0.835 \\
\hline & $\mathrm{X}_{14}$ & 0.686 & 0.833 & \\
\hline & $X_{15}$ & 0.690 & 0.837 & \\
\hline
\end{tabular}

can therefore be used to conduct further structural equation analyses.

According to the related theory of evaluating the goodness of fit of the structural equation model, three types of indicators are typically used to evaluate the goodness of fit of the model. (1) General fit indices (GFIs), normed fit indices (NFIs) and comparative fit indices (CFIs) have values that range from 0 to 1 ; higher values of these indices are indicative of a better fit. (2) The root mean square error of approximation (RMSEA) is used to assess a model; smaller RMSEA values are indicative of a better fit. In general, an RMSEA of less than 0.1 indicates a good fit and an RMSEA of less than 0.05 indicates a very good fit. (3) If a model has a value of CMIN / DF (the minimum discrepancy $\hat{c}$ is divided by its degrees of freedom) that is less than 5 , then the model in question can be regarded as a good fit. The fit indices of the modified structural equation model are as follows:

From Table 3, we observe that the goodness of fit of the modified model is very good. In addition, the chisquare value for the model is 100.619 , the model has 73 degrees of freedom and the probability level for the model
Table 3. The Goodness of Fit of the Model

\begin{tabular}{cccccc}
\hline Indices & GFI & CFI & NFI & RMSEA & CMIN/DF \\
\hline $\begin{array}{c}\text { Value } \\
\text { Evaluation }\end{array}$ & 0.954 & $\begin{array}{c}0.984 \\
\text { Good }\end{array}$ & $\begin{array}{c}0.946 \\
\text { Very good }\end{array}$ & $\begin{array}{c}0.037 \\
\text { Good }\end{array}$ & $\begin{array}{c}\text { Very good } \\
\text { Very good }\end{array}$ \\
\hline
\end{tabular}

is 0.018; these parameters also indicate that the model selection and calculation results are reliable. The following table 4 shows the estimation results.

The test results demonstrated that the market orientation of Chinese garlic farmers might enhance their performance but the result was not statistically significant, which cannot provide support for Hypothesis 1 of this study.

The test results for Hypothesis 2 revealed that Chinese garlic farmers' innovation had a positive impact on their performance; this result was significant at the 5\% significance level and supported Hypothesis 2. In other words, innovation inspired farmers to adopt new garlic varieties and technologies that increased their agricultural production and improved their performance.

The results for Hypothesis 3 indicated that Chinese garlic farmers' market orientation improved their innovation. This result was significant at the $1 \%$ significance level. In other words, farmers who considered the demands of consumers and the needs of channel partners experienced stronger motivation to accomplish planting innovation.

The results of the final hypothesis were extremely significant and important for small-scale Chinese farmers. In particular, this result, which was significant at the $1 \%$ significance level, demonstrated that farmers' strong strength of interpersonal relationships generated positive impacts on their market orientations. Interpersonal relationships provided Chinese farmers with the opportunity and resources to understand the purchasing needs of consumers and the desires of channel partners, allowing small-scale farmers to improve their market orientation. Through the mediators of market orientation and innovation, farmers' strength of interpersonal relationships also indirectly improved their performances.

The results also showed that other two additional groundless hypotheses failed to be testified and supported. We cannot find enough evidences that Chinese

Table 4. Results of the Parameter Estimations

\begin{tabular}{|c|c|c|c|c|c|}
\hline \multicolumn{3}{|c|}{ Path } & \multirow{2}{*}{$\begin{array}{l}\text { Estimate } \\
.780 * * *\end{array}$} & \multirow{2}{*}{$\begin{array}{l}\text { S.E. } \\
.098\end{array}$} & \multirow{2}{*}{$\frac{\mathrm{P}}{\text { *** }}$} \\
\hline Market Orientation & $<---$ & Interpersonal Relationship & & & \\
\hline Innovation & $<---$ & Market Orientation & $.346 * * *$ & .090 & $* * *$ \\
\hline Innovation & $<---$ & Interpersonal Relationship & -.077 & .088 & .385 \\
\hline Performance & $<---$ & Market Orientation & .188 & .129 & .145 \\
\hline Performance & $<---$ & Innovation & $.318 * *$ & .140 & .024 \\
\hline Performance & $<---$ & Interpersonal Relationship & .032 & .123 & .797 \\
\hline
\end{tabular}

Notes: *** and ** represent significant results at the $1 \%$ and $5 \%$ levels, respectively. 
garlic farmers' interpersonal relationships can positively improve their innovation and performance directly. Interpersonal relationship needs market orientation and innovation as mediators to impact the performance indirectly.

Some researches in other related field also proved that interpersonal relationships play an important role in Chinese farmers' economic activities. In the investigation data with the sample of 16 Chinese provinces, farmers who obtained loan through interpersonal relationships accounted for $60.09 \%$ and other $49.91 \%$ of them depended on banks (Zhou, 2012). Another survey data conducted in Beijing showed that $64.6 \%$ farmers got market information through interpersonal relationships and only $35.4 \%$ farmers depended on other information sources such as media, government and other institutions (Li, 2011). Liu (2008) applied a case to descript the role of interpersonal relationships to help farmers get better performance. The case took a rural community Z of Jilin province of China for example. Mr. Wang is one of pig breeding farmers in community Z. He made profits higher than other farmers every year and almost never lost from 1992 to 2007. The investigation showed that the most important reason was that Mr. Wang accumulated rich and strong power of interpersonal relationships. His connections with friends, relatives, feed suppliers, brokers, veterinaries, breeding farmers outside community $\mathrm{Z}$, and other business partners are very extensive and close, which helped him get sufficient and timely market information to make right breeding and marketing decisions. The result of our study also came to the conclusion that interpersonal relationships played a very important role in improving Chinese farmers' market orientation level.

Based on the above hypothesis testing, the estimated results demonstrate that Chinese farmers' market orientation can indirectly improve performance through the mediator of innovation. The coefficient for the effect of market orientation on performance would be 0.11 for the examined Chinese farmers. The results from this study that Chinese farmers' innovation could serve as a mediator to link market orientation and performance are consistent with the conclusions of previously published investigations that have examined various contexts from around the world. Furthermore, personal relationship played an important role of allowing small-scale Chinese farmers to obtain market information and improve their market orientation levels. Through the mediator of market orientation and innovation, farmers' interpersonal relationship could positively and indirectly improve their performances. The coefficient for the effect of interpersonal relationships on performance would be 0.09 for the examined Chinese farmers.

\section{CONCLUSIONS AND IMPLICATIONS}

The purpose of this research was to explore the relationship between Chinese garlic farmers' market orientations and their performance and to investigate the functional mechanisms underlying this relationship. We uti- lized survey data collected in 2012 from the main garlicproducing area of China to build a structural equation model and test our hypotheses. The goodness of fit of the model was first verified, and we then found that Chinese garlic farmers' market orientations positively impacted their performances. This effect occurs indirectly; in particular, the indirect effects utilize the mediator of innovation. In other words, farmers' market orientations not only allow these farmers to meet the needs of consumers and channel partners but also impact their innovation and performance. Our conclusions coincide with research into market orientation in the contexts of the American food industry, beef producers and Dutch horticultural farmers. In addition, given that the Chinese agricultural producers are generally composed of numerous, widely scattered small-scale farmers, we proposed a hypothesis that Chinese farmers' strength of interpersonal relationships could exert direct positive effects on market orientation and indirect positive effects on performance. The study results validated this hypothesis. This conclusion may reflect the fact that the Chinese government's provision of market information is inadequate; this reasoning represents a possible innovation of this study.

The empirical study of Chinese garlic farmers' performance reveals the importance of interpersonal relationships for the survival of small-scale farmers under conditions in which the government cannot provide a sufficient quantity of market information to the public. The implication for the Chinese government's agricultural marketing policy is that the government should fully understand and devote attention to farmers' strength of interpersonal relationships. Interpersonal relationships can generate direct positive impacts on farmers' market orientation levels and can provide indirect benefits to performance. In addition to addressing widespread market imperfections and information shortages, our results suggest that improving the relationship between farmers and buyers could also contribute to more widespread market information gathering by small-scale farmers; this process could further enhance these farmers' levels of market orientation, innovation and performance. In addition to utilizing farmers' interpersonal relationships strength, the Chinese government should provide more market data, such as information about channel demands, consumer needs, new varieties and new technology, to small-scale farmers; these data would allow these farmers to understand the desires of consumers and the needs of buyers. We anticipate that the introduction of the above measures should increase the market orientation levels of small-scale farmers. To meet consumers' needs and satisfy market desires, small-scale farmers who are guided by market orientation could institute a variety of innovations, such as the adoption of new varieties of crops and new planting technologies that could improve their performances.

There are certain limitations of this study. Gerbing (1985) indicated that for "three or more indicators per factor, a sample size of 100 will usually be sufficient for convergence", but it is widely accepted that larger sample sizes produce more reliable results. The second prob- 
lem is that variables other than market orientation and innovation may affect farmers' performance; for instance, these variables could include cost focus and entrepreneurial approach. This issue merits future investigation.

\section{ACKNOWLEDGMENTS}

The ideological inspiration that was provided by Professor Hamish Gow is greatly appreciated. We would also like to express our sincere gratitude to the graduate students who participated in conducting the survey: Yao Sheng, Zhang Xiaoheng, Ma Renlei, Shang Yongxing, Hu Lingxiao and $\mathrm{Gu}$ Chenglong.

This article is the result of a coordinated research program that involved the participation of various projects and donors that we would like to thank for providing funding for this study. In particular, the study was performed under the auspices of the following two projects: (1) "Input-output analysis of Chinese agribusiness: from the view of international comparativeness" (No. 71003050), which was funded by the National Natural Science Foundation of China (NSFC); and (2) "Direct Farm Project and its impact on the small farmers' behavior and income" (No. KYZ201162), which was funded by the Fundamental Research Funds for the Central Universities in China.

\section{REFERENCES}

Amos, T. T. 2007 An Analysis of Productivity and Technical Efficiency of Smallholder Cocoa Farmers in Nigeria. Journal of Social Science, 15(2): 127-133

Ashok, M., Wilson, C., \& Williams, R. 2009 Factors Affecting Financial Performance of New and Beginning Farmers. Agricultural Finance Review, 69(2): 160-179

Bentler, P. M., \& Chou, C. P. 1987 Practical Issues in Structural Modeling. Sociological Methods and Research, 16: 98-117

Brocke, K. V., Weltzien, E., Christinck, A., Presterll, T., \& Geiger, H. H. 2003 Effects of Farmers' Seed Management on Performance and Adaptation of Pearl Millet in Rajasthan, India. Euphytica, 130: 267-280

Chitere, P. A. \& Doorne, J. H. V. 1985 Extension Education and Farmers' Performance in Improved Crop Farming in Kakamega District, Kenya. Agricultural Administration, 18(1): 39-55

Cronbach, L. J. 1951 Coefficient Alpha and the Internal Structure of Tests. Psychometrika, 16(3): 297-334

Dhaka, B. L. \& Poonia, M. K. 2009 Impact of Training on Farmers Performance. Indian Journal of Training and Development, 4(6): $65-68$

Fan, Y. 2002 Questioning Guanxi: Definition Classification and Implications. International Business Review, 11: 543-561

Gerbing, D. W. \& Anderson, J. C. 1985 The Effects of Sampling Error and Model Characteristics on Parameter Estimation for Maximum Likelihood Confirmatory Factor Analysis. Multivariate Behavioural Research, 20: 255-271

Gudbrand, L., Kumbhakar, S. C., \& Hardaker, J. B. 2010 Determinants of Off-farm Work and Its Effects on Farm Performance: The Case of Norwegian Grain Farmers. Agricultural Economics, 41(6): 577-586

Guntoro. B. 2007 Motivation and Performance of Beef Cattle Smallholder Farmers in Central Java Indonesia. http://www. apeec.upm.edu.my/agrex/FULL\%20PAPER\%20PDF\%20 (AGREX08)/budi\%20guntoro-117.pdf

Haefele, S. M., Wopereis, M. C. S., \& Donovan, C. 2002 Farmers' Perceptions, Practices and Performance in a Sahelian Irrigated Rice Scheme. Experimental Agriculture, 38(2): 197-210

Han, J. K., Kim, N., \& Srivastava, R. K. 1998 Market Orientation and Organizational Performance: is Innovation a Missing Link? Journal of marketing, $\mathbf{6 2}$ (4): 30-45

Hansen, E., Dibrell, C. \& Down, J. 2006 Market Orientation, Strategy, and Performance in the Primary Forest Industry. Forest Science, $\mathbf{5 2}$ (30): 209-220

Hurley, R. F. \& Hult, G. T. M. 1998 Innovation, Market Orientation, and Organizational Learning: an Integration and Empirical Examination. Journal of Marketing, 62 (3): 42-54

Ishag, K., Thornton, D., Tiffen, M., \& Upton, M. 1991 Farm Location and Farmers' Performance on the Hamza Minor Canal. International Journal of Water Resources Development, 7(1): 2-15

Jaworski, B. J., \& Kohli, A. K. 1993 Market Orientation: Antecedents and Consequence. Journal of Marketing, 52(7): 53-70

Johnson, A. J., Dibrell, C. C., \& Hansen, E. 2009 Market Orientation, Innovativeness, and Performance of Food Companies. Journal of Agribusiness, 27(1): 85-106

Joyce, W., Dearyb, I. J., McGregora, M. M. A., Sutherlanda, G. E., Jonesa, O., Morgana, Dentc, B., Grieved, R., Gibsone, G., \& Austine, E. 1999 Farmers' Attitudes, Objectives, Behaviors, and Personality Traits: The Edinburgh Study of Decision Making on Farms. Journal of Vocational Behavior, 54(1): $5-36$

Kabiri, F., \& Mokshapathy 2012 Entrepreneurial Orientation and Farmers Performance: Evidence from Bushehr Province in Iran. Indian Journal of Education and Information Manage, 1: 7-17

Kim, J., \& Muller, O. 1978 Factor analysis: Statistical Methods and Practical Issues. Beverly Hills, CA: Sage Publications

Kohli, A. K., \& Jaworski, B. J. 1990 Market Orientation: the Construct, Research Propositions, and Managerial Implications. Journal of Marketing, 54(2): 1-18

Larson. A. 1991 Partner Networks: Leveraging External Ties to Improve Entrepreneurial Performance. Journal of Business Venturing, 6(3): 173-188

Lawal, B. O., Saka, J. O., Oyegbami, A., \& Akintayo, I. O. 2004 Adoption and Performance Assessment of Improved Maize Varieties among Smallholder Farmers in Southwest Nigeria. Journal of Agricultural \& Food Information, 6(1): 35-47

Li, H. 2011 The Fracture Phenomena in New Generation of Migrant Workers Employment Information Acquiring. Youth study, 2: 15-33

Liu, Y. H., Zhang, L., Wang, D. H. 2008 Analysis and Countermeasures of rural market information imbalance. Rural economy, 5: 104-109

Lu, H., Trienekens, J. H., Omta, S. W. F., \& Feng, S. Y. 2010 Guanxi Networks, Buyer-seller Relationships, and Farmers' Participation in Modern Vegetable Markets in China. Journal of International Food and Agribusiness Marketing, 22 $70-93$

Masuku, M. B. \& Kirsten, J. F. 2004 The Role of Trust in the Performance of Supply Chains: an Analysis of Smallholder Farmers and Processing Firms in the Sugar Industry in Swaziland. Agrekon: Agricultural Economics Research, Policy and Practice in Southern Africa, 43(2): 147-161.

Mavondo, F. \& M. Farrell. 2003 Cultural Orientation: It's Relationship with Market Orientation, Innovation, and Organizational Performance. Management Decision, 41(3): 241-249

Meike, W. \& M. Zeller. 2007 Do Farmers Benefit from Participating in Specialty Markets and Cooperatives? The Case of Coffee Marketing in Costa Rica. Agricultural Economics, 37(3): 243-248

Micheels, E. T. \& Gow, H. 2008 Market Orientation, Innovation and Entrepreneurship: An Empirical Examination of the Illinois Beef Industry. International Food and Agribusiness Management Review, 11(3): 31-56

Narver, J. C. \& Slater, S. F. 1990 The Effect of a Market Orientation on Business Profitability. Journal of Marketing, 54(10): 20-35

Nunnally, J. C. \& Bernstein, I. H. 1994 Psychometric Theory (3rd Ed.). New York: McGraw-Hill 
Slater, S. F. \& Narver, J. C. 1994 Does Competitive Environment Moderate the Market Orientation Performance Relationship? Journal of Marketing, 58(1): 46-55

Slater, S. F. \& Narver, J. C. 1998 Customer-led and Market Oriented: Let's Not Confuse the Two. Strategic Management Journal, 19(10): 1001-1006

Slater, S. F. \& Narver, J. C. 1999 Market-oriented is More Than Being Customer-led. Strategic Management Journal, 20(12): 1165-1168

Slater, S. F. \& Narver, J. C. 2000 The Positive Effect of a Market Orientation on Business Profitability: A Balanced Replication. Journal of Small Business Management, 42(1): 134-154

Standifird, S. S., \& Marshall, R. S. 2000 The Transaction Cost
Advantage of Guanxi-based Business Practice. Journal of World Business, 35(1): 21-42

Tarabla, H. D., \& Dodd, K. 1990 Associations Between Farmers Personal Characteristics, Management Practices and Farm Performance. British Veterinary Journal, 3: 157-164

Verhees, F. J. H. M, Lans, T., \& Verstegen, J. A. A. M. 2011 Entrepreneurial Proclivity, Market Orientation and Performance of Dutch Farmers and Horticultural Growers. EAAE 2011 Congress, ETH Zurich

Zhou, T. Y., Zhou, T. 2012 An Empirical Analysis of China's Rural Interpersonal Circle and the Mortgage Replacement. Chinese rural observation, 1: 46-53 